\title{
Rare association between penile squamous cell carcinoma and parathyroid related peptide (PTH-rP) secretion
}

\author{
Associação rara entre carcinoma de células escamosas do pênis \\ e secreção de peptídeo relacionado ao paratormônio (PTH-rP)
}

Rogelio Trejo-Rosales', Maria J. Nevarez-Barragan², Mercedes G. Rosas-Jurado ${ }^{2}$, Ivan Perez-Diaz' ${ }^{1}$ Ana Paula Piana Bezaury ${ }^{3}$

1 Internal Medicine, Division of Medicine. Instituto Nacional de Ciencias Medicas y Nutricion "Salvador Zubiran". Mexico City, Mexico

2 Instituto Tecnologico y de Estudios Superiores de Monterrey, Mexico City, Mexico

${ }^{3}$ Unidad PET/CT. Facultad de Medicina, UNAM.

Mexico City, Mexico

\section{Correspondence to:}

Ivan Perez-Diaz

Departamento de Medicina

(subdireccion medica),

Instituto Nacional de Ciencias

Medicas

y Nutricion "Salvador Zubiran",

Vasco de Quiroga XV,

Colonia Seccion XVI,

Delegacion Tlalpan

14000 - Ciudad de Mexico, Mexico

ivan.endocrino@gmail.com

Received on July/8/2013

Accepted on Apr/29/2014

DOI: 10.1590/0004-2730000002880

\begin{abstract}
We report on a rare case of an adult with severe hypercalcemia secondary to the ectopic secretion of parathyroid-related peptide (PTH-rP) from a penile squamous cell cancer (PC). A patient of 47 years old was admitted with warty lesions and areas of ulceration covered by purulent material in a large area of the groin, scrotum and penis. Laboratory tests revealed severe hypercalcemia and elevation of PTH-rP; the biopsy reported PC. Hypercalcemia was successfully treated with zoledronic acid, however, the tumor displayed aggressive behavior, which resulted in a poor prognosis for the patient. Arq Bras Endocrinol Metab. 2014;58(6):646-9
\end{abstract}

\section{RESUMO}

Relatamos um caso raro em um adulto com hipercalcemia grave secundária à secreção ectópica de peptídeo relacionado ao paratormônio (PTH-rP) de um carcinoma de células escamosas do pênis (CP). Um paciente de 47 anos foi admitido com lesões verrucosas e áreas de ulceração cobertas por material purulento em uma grande área da virilha, escroto e pênis. Os testes laboratoriais revelaram hipercalcemia grave e elevação do PTH-rP; a biópsia mostrou um CP. A hipercalcemia foi tratada de forma bem-sucedida com ácido zoledrônico. Entretanto, o tumor apresentava um comportamento agressivo, resultando em um prognóstico ruim para o paciente. Arq Bras Endocrinol Metab. 2014;58(6):646-9

\section{INTRODUCTION}

$\mathrm{H}$ ypercalcemia, like paraneoplastic manifestation, is responsible for more than $20 \%$ of complications related to cancer and up to $50 \%$ of patients, in which it is present, die within 30 days of diagnosis. Within the range of malignancies, PC is a rare neoplasia with an incidence rate of 0.91 per 100,000 (males) in Mexico. We report the case of an adult with severe hypercalcemia related to the ectopic secretion of PTH-rP for PC.

\section{CASE REPORT}

A 47-year-old man arrived at the emergency department of our institute with severe lesions in the genital area and groin, presenting fever, weight loss (around $8 \mathrm{~kg}$ in one year) and muscle weakness. The condi- 
tion began sixteen months prior, with a vesicular lesion over the glans, which had increased in size, finally becoming warty type, followed by other lesions of similar features that grew until they became confluent and covered a large zone of the genital area. A physical examination showed warty-like lesions, with ulceration and purulent material affecting the groin, scrotum and penis (Figure 1). On palpation, painful abscesses were identified. The biopsy of the lesion reported penile invasive squamous cell carcinoma. Initial laboratory tests showed leukocytosis $\left(30,500 / \mathrm{mm}^{3}\right)$, with $85.8 \%$ of neutrophils, with total serum calcium of $15.1 \mathrm{mg} / \mathrm{dL}$ (normal range $8.6-10.2 \mathrm{mg} / \mathrm{dL}$ ), corrected to albumin calcium level of $16.9 \mathrm{mg} / \mathrm{dL}$ and ionized calcium of $8.96 \mathrm{mg} / \mathrm{dL}$ (normal $4.5-5.3 \mathrm{mg} / \mathrm{dL}$ ), creatinine 1.95 $\mathrm{mg} / \mathrm{dL}$ (normal range $0.6-1.2 \mathrm{mg} / \mathrm{dL}$ ). The electrocardiogram showed normal Q-T interval. Due to these results, parathyroid hormone (PTH) was measured and very low levels of $2.5 \mathrm{pg} / \mathrm{mL}$ (normal range $12-88 \mathrm{pg}$ / $\mathrm{mL}$ ) were identified. PTH-rP was thus requested, and a very high value of $127 \mathrm{pg} / \mathrm{mL}$ (normal range 14-27 $\mathrm{pg} / \mathrm{mL}$ ) was found. The patient was managed with vigorous hydration and loop diuretics without achieving

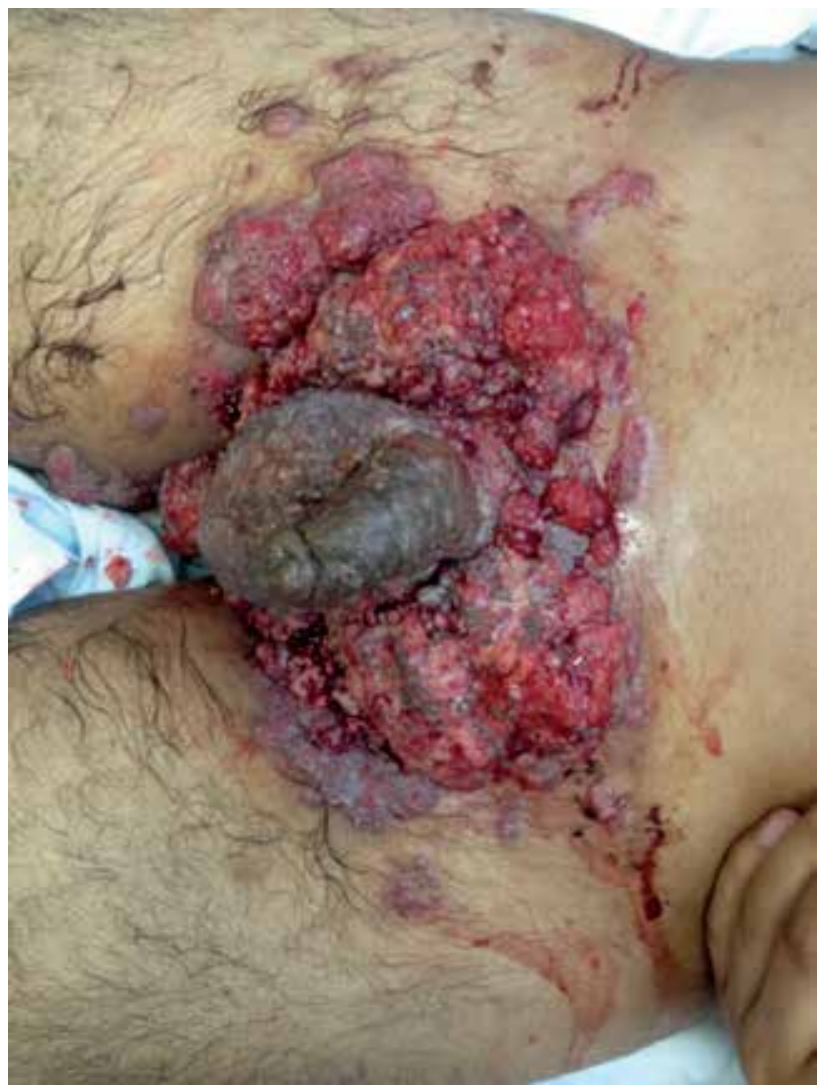

Figure 1. Showing invasive squamous cell cancer of the penis. Warty lesions appearance and areas of ulceration. a decrease in serum calcium levels. A dose of $4 \mathrm{mg}$ zoledronic acid was therefore infused, resulting in a remarkable response. Normal calcium levels were achieved by four weeks, at which time another dose was needed. Normal calcium levels were maintained until the final day of follow up (23 days later). Imaging studies (metastatic bone series, bone scan and CT scan) ruled out the presence of distant metastasis or lytic bone lesions, but extensive tissue invasion was evident (Figure 2). In an attempted tumor resection, the patient was given neo adjuvant chemotherapy (paclitaxel, cisplatin and ifosfamide) without success and caused worsening of the infectious process, presenting severe sepsis. Due to the unresectability of the tumor, coupled with the inability to control the infection, a decision to discharge the patient with palliative treatment was made.

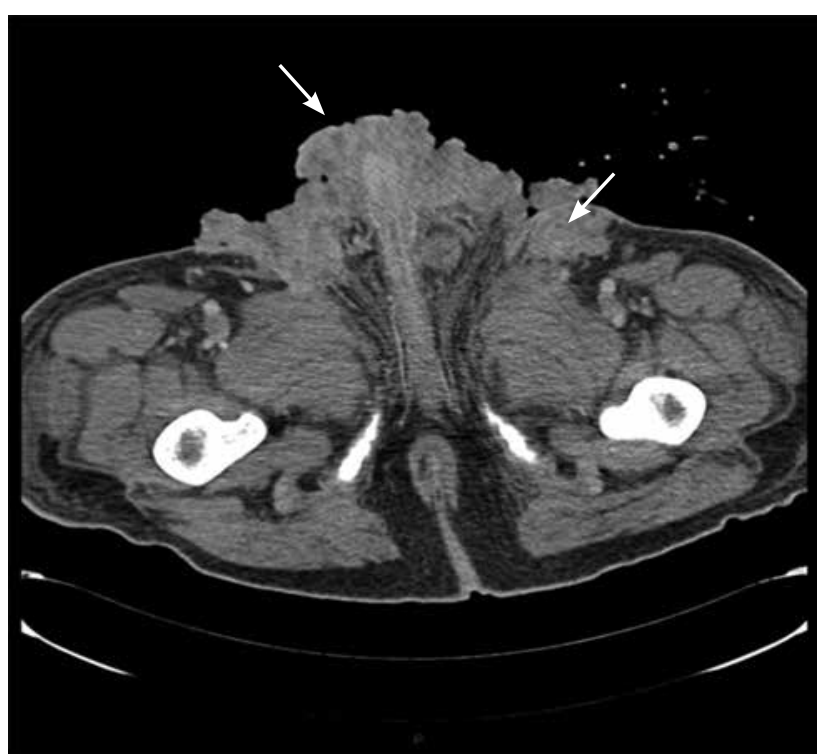

Figure 2. Computed tomography at the pelvis level shows a poorly defined heterogeneous lesion at the base of the penis and scrotum extending skin and subcutaneous tissue (white arrows).

\section{DISCUSSION}

Paraneoplastic hypercalcemia complicates up to $20 \%$ of neoplasms (1). The condition is characterized by an abrupt presentation and is associated with a poor prognosis, since $50 \%$ of patients with paraneoplastic hypercalcemia die within 30 days of diagnosis. In fact humoral hypercalcemia associated with cancer is the leading cause of severe hypercalcemia in hospitalized patients and is always associated with poor prognosis and poor treatment response (1). The mechanisms which result in the development of hypercalcemia of malignancy comprise humoral mechanisms and direct bone damage 
(lytic lesions) (2). A major cause of humoral mechanisms is the production of PTH-rP in about $80 \%$ of the patients, and less frequently, other molecules, including PTH and 1,25-dihydroxyvitamin D secreted by neuroendocrine tumors and increased $1 \alpha$-hydroxilase activity in lymphoproliferative disorders (2). PTH-rP and PTH are related molecules and both activate the same type I receptor (PTHRl) (3). PTH-rP is a protein consisting of 144 amino acids with $\mathrm{N}$-terminal sequence homologous to PTH that increases calcium levels similarly to PTH, except that it does not increase the synthesis of 1,25-dihydroxyvitamin D to the same extent as PTH and does not induce increased gastrointestinal calcium absorption (3). Furthermore, PTH-rP stimulates mainly osteoclasts activity and shows a very low osteoblastic activity (2). PTH-rP activates osteoblasts to produce receptor activator of nuclear factor- $\kappa$ ligand (RANKL). RANK, the receptor for RANKL on preosteoclasts, binds RANKL, which induces preosteoclasts to become mature osteoclasts (4). Additionally, PTH-rP decreases the production of osteoprotegerin, increasing osteoclast numbers and activity(4). Finally, transforming growth factor b production due to osteolysis greatly increases PTH-rP production by the tumor cells (4).

Many cell types and organs, like human keratinocytes, lactating breast, brain, muscle, bone, ovary and parathyroid glands, produce PTH-rP in low levels, but its functional significance is still being clarified (4). Abnormal presence can be manifest in neoplasms, such as small cell lung cancer, breast cancer and cervical cancer, although it is rare in penile squamous cell carcinoma, with very few cases being reported to our knowledge $(1,5,6)$. In such cases, the treatment of hypercalcemia will depend on the patient's condition and its severity. Treatment options may include hydration, the use of loop diuretics and bisphosphonates, in addition to decreasing the tumor burden with chemotherapy and tumor resection $(6,7)$. However, in our patient, it was impossible to perform surgical resection of the tumor, due to its large size and the severity of the tumor infection. Due to unresponsiveness to hydration and diuretics, the hypercalcemia was treated with zoledronic acid showing an adequate response, even presenting hypocalcemia at the fourth day after the first dose (serum calcium of $7.4 \mathrm{mg} / \mathrm{dL}$ ). Another dose of zelodronic acid was required one month after the first, as a result of new elevation of serum calcium levels. The second dose normalized and maintained the calcium level in normal range until the last day of monitoring (23 days later). The patient was then discharged and received palliative care.

$\mathrm{PC}$ is an uncommon neoplasia, with an incidence rate in the United States of 0.7-0.9 per 100,000 inhabitants. In Mexico, the histopathological record of malignancies during 2003, reported 346 cases, with an incidence rate of 0.91 per 100,000 males. These cases represent $0.31 \%$ of the total malignances and the rate of frequency is $1.1 \%$ (8). The mortality rate is 0.2 per 100,000 inhabitants, of which $0.17 \%$ represents cancer associated deaths $(8,9)$. Risk factors include deficient hygiene, smoking, phimosis, chronic inflammation of the penis and exposure to Human Papilloma Virus (especially serotypes 16, 18, 45,56 which were identified in $40 \%$ of cases). Probably, in our patient a poor hygiene and lack of circumcision were the predisposed factors to develop PC. In 95\% of cases, the histological characteristics of the tumors matched squamous cell carcinoma, as was in the case of our patient. The association between PC and hypercalcemia due to the production of PTH-rP is extremely uncommon, although a very few case reports do exist (9-11). Malakoff and Schmidt also describes a patient with PC secreting PTH-rP and serious hypercalcemia (12). Management of the hypercalcemia included oral biphosphonates, hydration and diuretics, and the patient showed only a temporary response. In another case of ectopic secretion of PTH-rP for PC, published in Japan, the patient's hypercalcemia was managed with a multiple scheme, which included intravenous biphosphonates, calcitonin and diuretics, similarly showing a transient decrease in serum calcium (6). In the case presented, the patient achieved a prolonged response (one month) with zoledronic acid infusion. Unfortunately in this patient a measurement of vitamin $\mathrm{D}$ was not carried out, since a deficiency of vitamin D might explain the good response to zoledronic acid treatment. However when an adequate response is not achieved to maintain normal calcium levels with bisphosphonate used alone, a human monoclonal antibody against RANKL, Denosumab has been successfully employed. Denosumab cause a reduced rate of bone resorption through inhibition of osteoclast maturation, activation, and function (13).

On the other hand, there is an uncommon association among PC, hyperleukocytosis and hypercalcemia as paraneoplastic manifestations. Both disorders could be considered as secondary to the tumoral production of PTH-rP like physiopathological mechanism. There is only one documented case in medical literature that conveys this association $(14,15)$. By the time our pa- 
tient was admitted, he presented leukocytosis levels of $30,500 / \mathrm{mm}^{3}$. However, it was clearly accompanied by an infectious process of the tumor. The leukocytosis was partially normalized through the administration of a broad-spectrum antibiotic, which suggests that it was secondary to the infectious process.

This case report presents a patient with invasive PC associated with malignant hypercalcemia due to production of PTH-rP. The vast extent of the injury and its infection limited the surgical and chemotherapy treatment options, worsening the patient's prognosis. The hypercalcemia was clearly attributed to paraneoplastic PTH-rP secretion by the tumor and was temporarily controlled with the use of zoledronic acid, which can be safely and effectively used in these patients.

Acknowledgment: the authors would like to thank Dora Luz Barragan Patraca, MD, from Universidad Popular Autonoma del Estado de Puebla for her assistance in reviewing the images, and Nyran Rasche for proof-reading the manuscript.

Disclosure: no potential conflict of interest relevant to this article was reported.

\section{REFERENCES}

1. Jibrin IM, Lawrence GD, Miller CB. Hypercalcemia of malignancy in hospitalized patients. Hospital Physician. 2006:29-35.

2. Lumachi F, Brunello A, Roma A, Basso U. Cancer-induced hypercalcemia. Anticancer Res. 2009;29:1551-6.
3. Holick MF. Vitamin D deficiency. N Engl J Med. 2007;357:266-81.

4. Reagan P, Pani A, Rosner MH. Approach to diagnosis and treatment of hypercalcemia in a patient with malignancy. Am J Kidney Dis. 2013;63(1):141-7.

5. Stewart AF, Horst R, Deftos LJ, Cadman EC, Lang R, Broadus AE. Biochemical evaluation of patients with cancer-associated hypercalcemia: evidence for humoral and nonhumoral groups. N Engl J Med. 1980;303:1377-83.

6. Akashi T, Fuse H, Muraishi Y, Mizuno I, Nagakawa O, Furuya Y. Parathyroid hormone related protein producing penile cancer. $J$ Urol. 2002;167:249.

7. Anderson EE, Gleen JF. Penile malignancy and hypercalcemia. JAMA. 1965;192(4):328-9.

8. Jiménez MA, Solares M, Martínez P, Martínez J, Hinojosa J, Zamora J, et al. Oncoguía: Cáncer de pene. Cancerología. 2011;6:7-11.

9. Medina EA, Ibáñez AO, Martínez R, Barra R, Quezada I, Pérez JA, et al. Cáncer de pene. Revisión de las características clínico-patológicas. Gac Mex Oncol. 2012;9(6):282-96.

10. Gleen JF. Hypercalcemia and urologic malignancies. Urology. 1995;41(1):139-41.

11. Dorfinger K, Maier U, Base W. Parathyroid hormone related protein and carcinoma of the penis: paraneoplastic hypercalcemia. $J$ Urol. 1999;161(5):1570.

12. Malakoff AF, Schmidt JD. Metastatic carcinoma of penis complicated by hypercalcemia. J Urol. 1975;5(4):510-3.

13. Freeman A, El-Amm J, Aragon-Ching JB. Use of denosumab for renal cell carcinoma-associated malignant hypercalcemia: a case report and review of the literature. Clin Genitourin Cancer. 2013;11(4):e24-6.

14. Doraiswamy A. Leukocytosis and hypercalcemia: a rare combination of paraneoplastic features in squamous cell penile cancer. South Med J. 2010;103 (5):474-6.

15. Santiago AC, Soriano J, Calvo JB, Guevara B, Carrera E, Durán MA. Sindrome de leucocitosis e hipercalcemia asociada a carcinoma epidermoide de pene. Presentación de un caso. Rev Med Hosp Gen Mex. 2004;67(2):98-1. 